\title{
Monitoring and Evaluation Information System Modeling for Banking Credits
}

\author{
Mercurius Broto Legowo \\ Faculty of Information Technology, Perbanas Institute, Jakarta, 12940, Indonesia
}

\begin{abstract}
The aim of this study is to develop the concept of monitoring and evaluation to support the Modeling of Information Systems for banking credits (Regional Development Bank in Indonesia, as a case study). Problems arise when the banking institution has a percentage of non-performing loans (NPL) greater than or equal to $5 \%$, which indicates that the banking lending system has some disadvantages that is lead to the need of a monitoring and evaluation. The Enterprise Knowledge Development - Change Management Method (EKD-CMM) provides multiple and dynamically constructed ways of working to organize and to guide the enterprise knowledge modeling and organizational change processes. The expected results of this research is to build an information systems model to help in monitoring and evaluating the performance of banking credits. The evaluation of the proposed model shows that the framework is reliable and beneficial for the development of banking credits system and also provide significant implications.
\end{abstract}

Keywords: Monitoring and Evaluation, Information System, Modeling, Banking Credits.

\section{Introduction}

As we know the main activity in banking is fund channeling to the public, which is in banking institutions commonly referred to as bank credits. According to the Law of the Republic of Indonesia Number 10/1998, a Bank is defined as an entity that collects public money in the form of deposits and channel back to the community in the form of credits or other as an effort to improve people's lives [1]. A security issue of banking credits is an imperative matter that must be considered by the bank, because of the risks that arise credits delivery system. A key indicator which describes a healthy state of distributed fund from banking institution, widely known as "credit, is the Non Performing Loan (NPL) value that is less than 5\% [1]. However, in today's reality, there are still many banking institutions that have NPL value which is above $5 \%$. In relation to this actuality, the Indonesia Central Bank, known as the Bank of Indonesia (BI), has also stated that most of the Indonesia Regional Development Bank (BPD) are experiencing difficulties in managing the distributed loans, names as the "Kredit Usaha Rakyat"
(KUR), that they are providing to the community [2]. This problem can be avoided by providing an adequate internal control specifically in the area of credit distribution. In others words, we need a monitoring and evaluation system model that can support the effectiveness and efficiency for the system of banking credits.

Kusek et al in their study has stated that monitoring activities should focus more on the ongoing activities [3]. Based on the OECD [4] it was defined that the evaluation is a systematic and objective assessment of a project, program, or policy of ongoing or completed tasks to confirm that the implementation of activities are on track (within the guidelines and program planning). Thus, a Monitoring and Evaluation system is a management toolkit that enables decision makers to track progress and demonstrate the impact of a particular program [5]. The purpose of this system is to provide information to program managers in the event of obstacles and irregularities, as well as input in the evaluation.

According to the Indonesian Bankers Association, credit is one of the main channel that provides income for banking institution, yet it is also followed by a state of risk that needs to be considered [1]. Therefore, monitoring and evaluation is very desirable in making the provision of credit by a bank. This is to prevent the credit problems from emerging in the future. Along with this, in today's business activities, the Information Systems is also significantly influencing the daily life of the community particularly in the banking credits management. Consequently, a management information system (MIS) is a strategy and a set of protocols to enable people to obtain the information they need to manage their business [5]. A monitoring and evaluation information system (MEIS) is one type of MIS that was designed to mitigate poor business performance, demonstrate accountability and promote organizational learning for the benefit of future business [6].

This study, focus in the MEIS modeling for the distribution of funds to the public, with a credit case from one of the Regional Development Bank in Indonesia named the XYZ Bank. The utilized modeling technique is the Enterprise Knowledge Management Development-Change Method 
(EKD-CMM) approach, which was introduced by Nurcan and Barrios [7]. Additionally, the study applies an applied research with qualitative approach [8] as the methodology to realize the research objective. In relation to this, some preliminary studies are needed, particularly to comprehensively understand the concept of monitoring and evaluation systems as well as the process of credit distribution in the banking system.

Some studies related to monitoring and evaluation system for bank credit that has been done before. Some studies that discuss the Regional Development Bank[2], The application of the concept of Monitoring and Evaluation addressed to the application of the concept of monitoring and evaluation with an implementation project [6] and research related to the process of monitoring and evaluating the distribution of funds for project development and economic growth in Kenya[9], and Modeling Information System Monitoring and Evaluation in the case BAPPEDA in Manado using Agile approaches and Spatial Method [10].

Theoretically, this study contributes to development of science and business information system, particularly in applying a model of information system for monitoring and evaluation in banking. For in this case, a banking credit problem in the "XYZ" Regional Development Bank in Indonesia.

\section{Literature Review}

The process of granting credit to the public by the banks need a way of monitoring and evaluation in a model information system, thus providing good benefits for the bank.

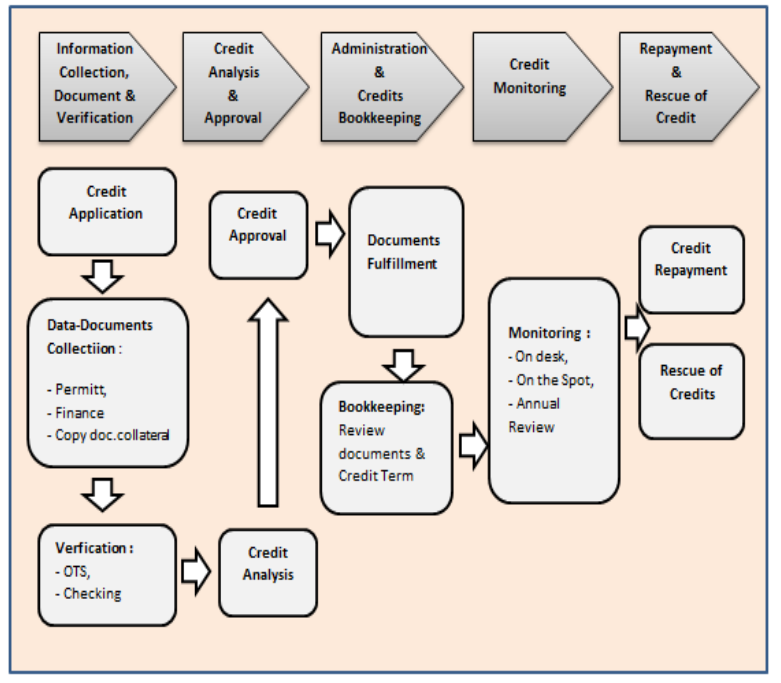

Fig. 1 Banking Credit Process

\subsection{Banking Credit Process}

According to Indonesian Bankers Association (Ikatan Bankir Indonesia (IBI), in Indonesia) defines that credit is one of the bank's risky business, but on the other hand provide income from lending [1]. Therefore, credit must be carried out by a clerk / credit who know and understand the basics of credit. Credit process requires a deep understanding that the way of credit, from loan processing to loan repayment goes well As for the credit approval process is generally in the banking business can be described, as in Figure 1.

\subsection{Monitoring and Evaluation Concept}

Monitoring is a routine, ongoing, internal activity which is used to collect information on a programs activities, outputs, and outcomes to track its performance[3]. Evaluation, as gleaned from the OECD [4], is a systematic and objective assessment of an ongoing or completed project, program, or policy. The aim is to determine the relevance and fulfillment of objectives, development efficiency, effectiveness, and impact. The evaluation process provides an explanation of why the results, targets and results, or not, is achieved. A project monitoring and evaluation information system (MEIS) is one type of MIS designed to mitigate poor project performance, demonstrate accountability and promote organizational learning for the benefit of future projects [5]. Referring to a study conducted for the success of NGO projects can be described as the Mind Map below:

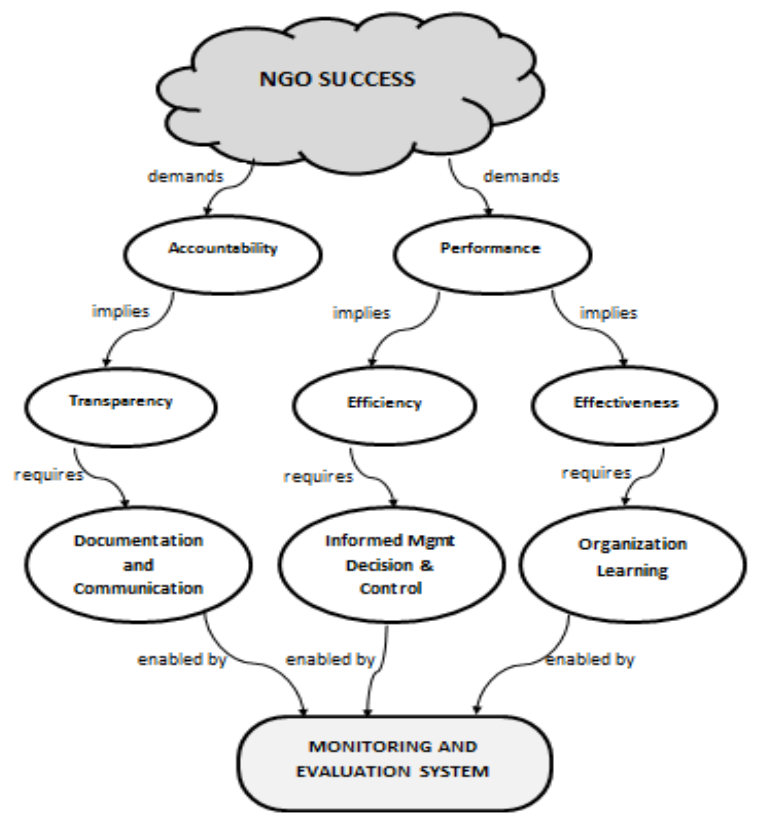

Fig. 2 Mind Map of the NGO Operating Enviroment [5] 
According to Crawford and Bryce study[6], that the M \& E Project implementation overview is usually used by the Logical Framework Approach (LFA). An outcome of using the LFA is the production of a $5 \times 4$ matrix (commonly known as the "log-frame"). The activity description can be derived from the matrix by breaking down the chain of "conditional causality" (If-And-Then Logic ).

\subsection{Information System Modeling}

According James $\mathrm{O}$ Brien[11], stated that Information System is a combination of each unit run by (people), hardware (hardware), software (software), computer networks and data communication networks (communication), and databases (database) that collect, transform, and distribute information about that form of organization. A management information system (MIS) is a strategy and a set of protocols to enable people to obtain the information they need to manage[6]. In spite of these important technological progresses, information systems that support business, do not usually answer efficiently enough to the continuous demands that organizations are faced with, causing non-alignment between business and information technologies (IT) and therefore reducing organization competitive abilities[12]. To implement the information systems within an enterprise, previously required an information system modeling. Information system modeling is concerned with how a system is realized by using information technology support. Information system modeling is an activity mostly the information technology that tries to interpret the application model into the building of operational systems. Modeling a system to deal with the details of specification that describes how the parts of the system will be realized. Modeling Information Systems typically use process modeling and data modeling[11]. System models have effective place in any system development. In order to illustrate a process model, data flow diagram (DFD) is needed[13]. In process modeling, the highest-level of data flow diagram is known as the context diagram. Process model is very important in defining the requirements in a graphical view [14]

Furthermore, based on the context diagram, the processes can be decomposed into a data flow diagram with more detailed level. Yakubu et al [13] stated that data modeling is a technique for organizing and documenting a system's data. Sometimes it is called database modeling because a data model is eventually implemented as a database. Entity relationship diagram (ERD) is the actual model that is frequently used. More clear and complete description of the modeling of information systems, it is usually also illustrated with Information Systems Architecture. The Information System Architecture (or ISA, for short) represents the structure of the components, their relationships, principles and directives with the main purpose of supporting business[12]. While software architectures represent internal system details (using, for example, E-R and DFD diagrams) ISA focus on the highlevel business processes. Nurcan and Barrios[7] in their research have developed a model of information system called as Enterprise Knowledge Management Development- Change Method (EKD-CMM )In this information system modeling begins with determining the enterprise business goal (Business Goal Model), and then make the details of enterprise processes (Business Process Model), which finally creates a model information system (Information System model), as can be seen in Figure 3.

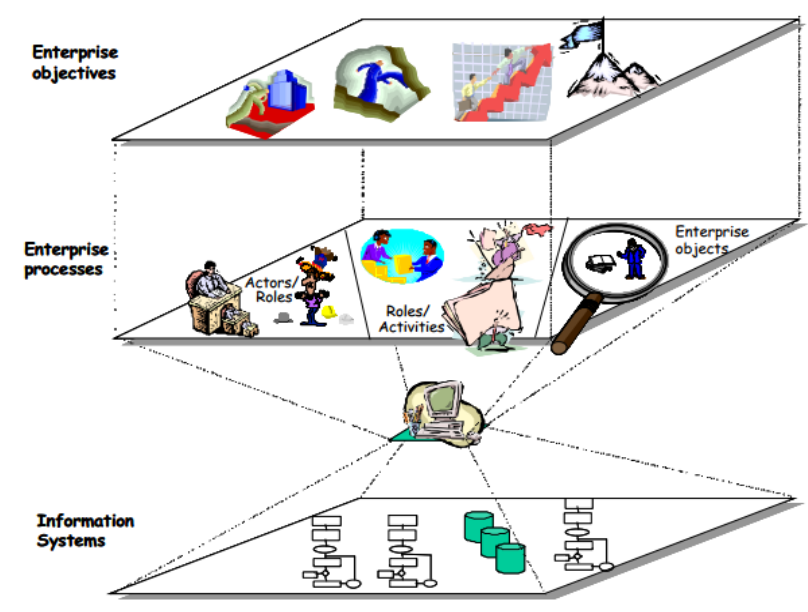

Fig. 3 Development of IS Model with EKD-CMM [7]

EKD-CMM is a method to documenting an enterprise, its objectives, business processes and support systems, helping enterprises to consciously develop schemes for implementing changes [7].

\subsection{MEIS Framework}

Based on M \& E Concept, Credits Banking process and The Information System Model using EKD-CMM approached than developed a conceptual framework., as describe in Figure 4.

The conceptual framework of monitoring and evaluation information system for bank credits, as in figure 4, can be explained as follows:

1. The purpose of this business is the monitoring and evaluation of bank credit. This objective was made to overcome the problems of the low NPL Banking and improve the quality of credit. The concept of $\mathrm{M} \& \mathrm{E}$ used in modeling information systems of monitoring and evaluation of bank credit $[3,45]$. 
2. Business Process Model is the Banking Credit process is a standard set by Bank Indonesia as the Central Bank of Indonesia [1].

3. Model Information System to be developed is the Monitoring and Evaluation Information System Modeling for the Bank Credits, in this case study on Bank XYZ as one of the Regional Development Bank in Indonesia. In information system modeling will be illustrated with process and data modeling [13] and information systems architecture [12].

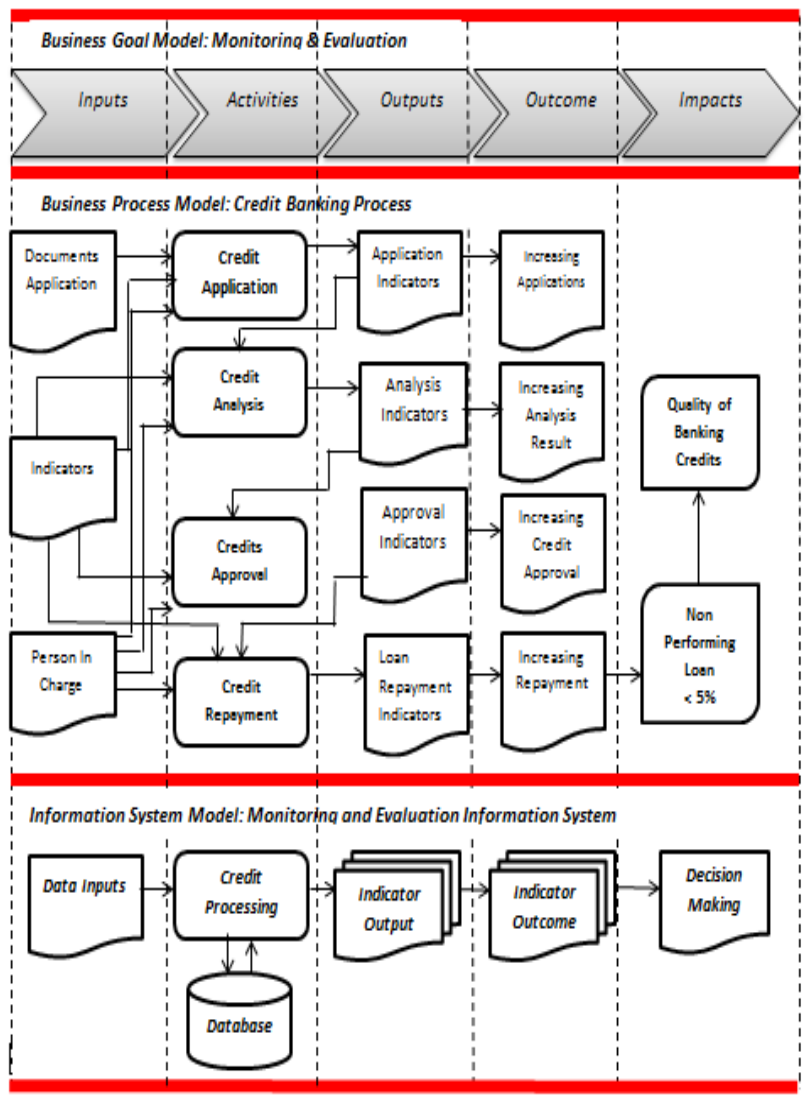

Fig. 4 MEIS Framework for Banking Credits

\section{Research Methodology}

The research was conducted in Indonesia by taking one of Regional Development Bank, namely the Bank $\mathrm{XYZ}$, as a case study. In relation to this, the study utilized the applied research with qualitative approach as its main methodology [8]. In particular, model of information system is developed using the Enterprises Knowledge Development-Change Management Method/EKD-CMM as it was introduced by Nurcan and Barrios in 2003 [7]. In this study, primary data is collected directly from the respondents. Consequently, the collected data is constructed from the collection of interviews' responses or results from the assessment process to identify the importance of a banking credit system.

In this study, in-depth interviews with respondents is conducted i.e. with the Chairman of Bank XYZ, where the result is produced by implementing the qualitative analysis. Descriptively, this research generates a model of information system. Furthermore, we conduct an evaluation phase to confirm and declare the reliability and validity of the model, this type of evaluation is named the confirmability test as stated by Sekaran in [8]. Later, to complete the test we invited the Information System practitioners and the experts in banking information system, which addresses the problems of bank credit and have comprehensive understanding of information system modeling.

\section{Results and Discussion}

In this section, we first described the case studies of credit and their related problems that occurred in Bank XYZ. Furthermore, the study will construct a model for monitoring and evaluation information system to overcome the problems that are related to banking credit as well as the implications of this MEIS model.

\subsection{Case Study}

Regional Development Bank is the key partner of the Provincial Government in Indonesia that supports the working program of the Provincial Government who required financial services and banking. Therefore, to be able to provide excellent financial services for the Provincial Government, the Regional Development Bank must consider the utilization of information technology to support their business. However, there are only few Regional Development Banks in Indonesia that has already developed banking products with information technology as their core system, such as the mobile banking and the Internet banking.

The results of in-depth interviews with the Chairman of Bank XYZ, has found that the ratio of non-performing loans (NPLs) increased from 1.04\% in 2013 to $1.54 \%$ in October 2014 and the conditions in the last year of $6.4 \%$. Despite the decline in performance in 2014, Bank XYZ remains optimistic that their earnings will increase by the end of this year. The underlying reason of this believe, is the actuality that there are opportunities as long as the credit expansion is going well and there was no increase in non-performing loans coming year. In relation to the condition of increasing NPL, then Bank XYZ should 
consider how to decrease their NPL level so that the quality of the provision of credit would become better. To accomplish such objective, an exact information system model to monitor and evaluate banking credit is required by the management to help in making fast and accurate decision.

\subsection{MEIS Modeling Results and Analysis}

The analysis of this study was based on a method of management changes at the bank. The importance of monitoring and evaluation in bank credit to minimize nonperforming loans and the quality of banking credits. Furthermore, by developing a knowledge enterprise or referred to as "Enterprise Knowledge DevelopmentChange Management Method". The end result is Model Information System Monitoring and Evaluation of Credit Bank, specifically in Bank XYZ.

\subsubsection{Business Goal Model}

Business Purpose of the organization XYZ Bank is conducting monitoring and evaluation for bank credit in order to minimize the NPL ( NPL $<5 \%$ ) and increase Banking Credit Quality. Model Business Goals by applying the concept of Monitoring and Evaluation, with a monitoring and evaluation system based on results[3]

\section{Mind Map:}

Mind Map is used to establish a monitoring and evaluation system of credit based on business objectives, the credit repayment. Thus, business objectives to improve the quality of bank credit can be achieved, with the amount of NPL $<5 \%$. To achieve these objectives, it demanded accountability and a good performance of the organization which is owned by Bank XYZ.

Accountability implies transparency of credit management, while the performance management implies that management should be able to effectively and efficiently manage the provision of credit. Good transparency will be achieved if the requirements of documentation and communication executed properly. Efficiency is achieved when the control and management decisions can be precisely and accurately. Learning organizations as well as a condition for the achievement of management effectiveness. If the documentation and communication, control and management decisions can be quickly and accurately as well as organizational learning is done well then the monitoring and evaluation system for bank credit will be easy to implement. Figure 5 shows the Mind Map for MEIS in Banking Credits

\section{Log Frame Approach:}

Log Frame is an approach to program planning / project created logically using clear indicators. In this case, the bank loan program by the Regional Development Bank $\mathrm{XYZ}$. Log Frame follows the concept of M \& E, which is a matrix formulation.

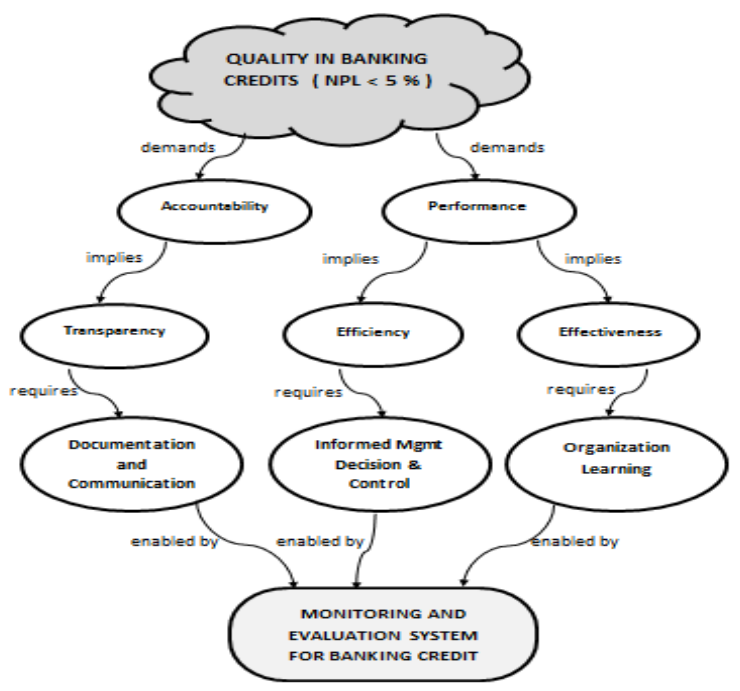

Fig. 5 Mind Map for MEIS

First made logic "IF - AND - THEN". This logic can be explained as follows:

IF Accepting Credit Application documents, AND assuming Credit Application files collected, THEN Reports for Credit Applications

IF Reports for Credit Application has been made, AND Files and documents have been fulfilled, THEN Increased credit application received IF Credit application has been received, AND Credit Application Process Completed, THEN Perform Credit Analysis.

\section{IF Perform Credit Analysis,}

AND accept Credit Application to be analyzed THEN The results of credit analysis completed IF Make Credit Analysis,

AND accept Credit Application to be analyzed THEN The results of credit analysis completed IF Increased credit analysis results AND credit analysis process completed, THEN Perform Credit Approval. 


\section{IF Perform Credit Approval}

AND Available credit analysis results have been resolved, THEN Make Credit Approval.

IF Make Credit Approval,

AND Fulfillment of the document completed

THEN Increased Credit Approval.

IF Increased Credit Approval,

AND Credit Approval process completed

THEN Implement Credit Monitoring

IF Implement Credit Monitoring,

AND Credit Approval has finished,

THEN The conduct of credit monitoring.

IF Conducting Credit Monitoring

AND Bookkeeping credit already done

THEN Increased implementation of credit monitoring.

IF Increased implementation of credit monitoring

AND Credit monitoring results are completed

THEN Implement Loan Repayment

IF Implement Loan Repayment,

AND Evidence of the monitoring results of Credit

THEN Make a statement credit repayment.

IF Created statement credit repayment,

AND Credit monitoring has been carried out

THEN Increased Loan Repayment

IF Increased Loan Repayment,

AND Loan repayment process completed,

THEN Business Goals achieved (Increased Bank Credit quality with NPL $<5 \%$ )

Furthermore, based on this logic, then the matrix monitoring and evaluation of banking credit with Bank $\mathrm{XYZ}$, created as shown in Table 1.

\subsubsection{Business Process Model}

The main process in this case is the process of banking credits. Based on this, it can be explained as follows:

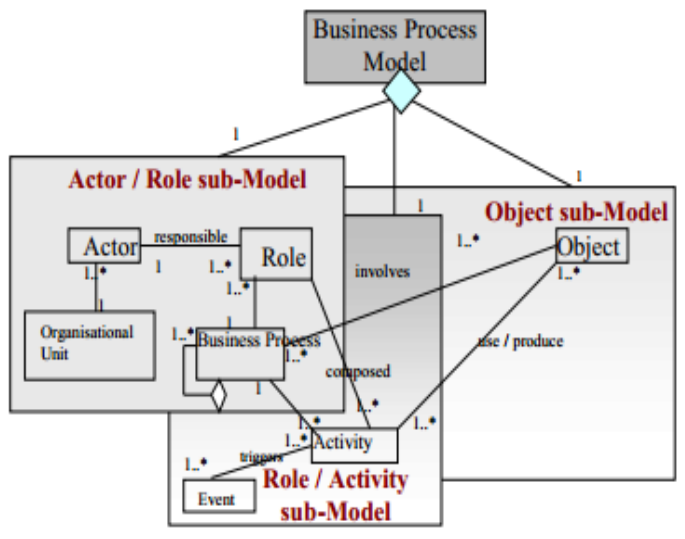

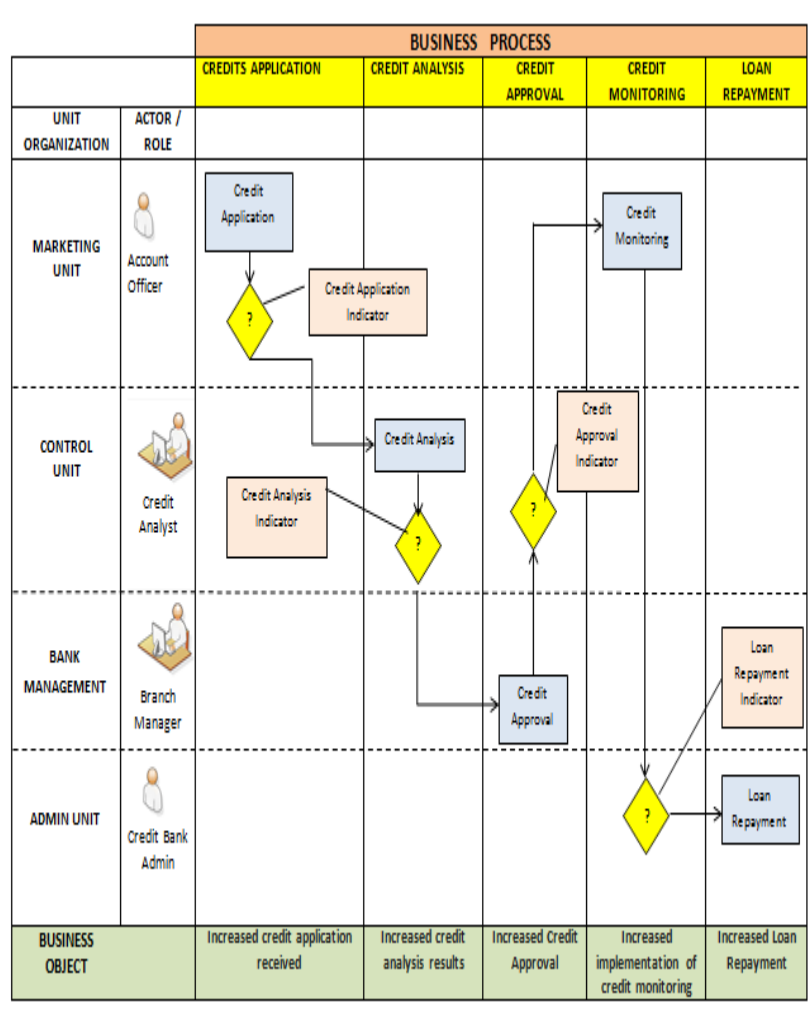

Fig. 7 Business Process Model of MEIS

It represent all business elements in banking involved in business processes execution as shown in Figures 7 .

\subsubsection{Information System Model}

The Information System Model should contain not only the set of information systems (IS), but the definition of the local and shared databases, as well as the information requirements and management indicators that should be satisfied by different applications[7]. Figure 8. shows below, the main concepts included as part of the Information Systems model. The object model is a refinement of the business object model which is a submodel of the second level. It must be refined and expressed according to the adopted software engineering techniques. The way this Information System model has been structure assures the business process are at the origin of the business objects are well as the definition of information requirement and management performance indicators. In consequence, they will be taken into account for the design and distribution of ICT components.

Fig. 6 Business Process Model [7] 
Table 1: The Logical Framework Approach for Banking Credit M \& E System

\begin{tabular}{|c|c|c|c|}
\hline Structure & $\begin{array}{c}\text { Objectively Verifiable } \\
\text { Indicator ( OVI ) } \\
\end{array}$ & $\begin{array}{c}\text { Means of Verification } \\
\text { ( MOV) }\end{array}$ & Assumptions \\
\hline \multicolumn{4}{|l|}{ Goal / Impact } \\
\hline $\begin{array}{l}\text { Business Goal } \\
\text { Achievement } \\
\text { (Increased Quality of } \\
\text { Credit } \\
(\mathrm{NPL}<5 \%)\end{array}$ & $\begin{array}{l}\text { All credit process completed, } \\
\text { and have impact for NPL }\end{array}$ & NPL Percentage & \\
\hline \multicolumn{4}{|l|}{ Purpose / Outcome } \\
\hline $\begin{array}{l}\text { Increased Loan } \\
\text { Repayment }\end{array}$ & Quantity of Loan Repayment & Loan Repayment Report & $\begin{array}{l}\text { Loan repayment process } \\
\text { completed }\end{array}$ \\
\hline $\begin{array}{l}\text { Increased } \\
\text { implementation of } \\
\text { credit monitoring }\end{array}$ & $\begin{array}{l}\text { Quantity of implementation for } \\
\text { credit monitoring }\end{array}$ & Credit Monitoring Report & $\begin{array}{l}\text { Credit monitoring has been } \\
\text { carried out }\end{array}$ \\
\hline $\begin{array}{l}\text { Increased Credit } \\
\text { Approval }\end{array}$ & Quantity of Credit Approval & Credit Approval Report & $\begin{array}{l}\text { Credit Approval process } \\
\text { completed }\end{array}$ \\
\hline $\begin{array}{l}\text { Increased credit } \\
\text { analysis results }\end{array}$ & $\begin{array}{l}\text { Quantity of Credit Analysis } \\
\text { results }\end{array}$ & Credit Analysis Report & $\begin{array}{l}\text { Credit Analysis process } \\
\text { completed }\end{array}$ \\
\hline $\begin{array}{l}\text { Increased credit } \\
\text { application received }\end{array}$ & Quantity Credit Application & Credit Applications Report & $\begin{array}{l}\text { Credit Application Process } \\
\text { Completed }\end{array}$ \\
\hline \multicolumn{4}{|l|}{ Output } \\
\hline $\begin{array}{l}\text { Created statement } \\
\text { credit repayment }\end{array}$ & Loan repayment completed & Loan repayment records & $\begin{array}{l}\text { Credit monitoring has been } \\
\text { carried out }\end{array}$ \\
\hline $\begin{array}{l}\text { The conduct of credit } \\
\text { monitoring }\end{array}$ & Bookkeeping credit fulfillment & Bookkeeping credit records & $\begin{array}{l}\text { Bookkeeping credit have } \\
\text { been fulfilled }\end{array}$ \\
\hline $\begin{array}{l}\text { Credit Approval has } \\
\text { made }\end{array}$ & $\begin{array}{l}\text { The document and credit term } \\
\text { have been fulfilled }\end{array}$ & Credit Approval Letter & $\begin{array}{l}\text { Credit term and documents } \\
\text { have been fulfilled }\end{array}$ \\
\hline $\begin{array}{l}\text { Credit analysis results } \\
\text { have been resolved }\end{array}$ & $\begin{array}{l}\text { Data and Document } \\
\text { Verification results }\end{array}$ & Credit Analysis results & $\begin{array}{l}\text { Checking and Verification } \\
\text { results has done }\end{array}$ \\
\hline $\begin{array}{l}\text { Reports for Credit } \\
\text { Applications }\end{array}$ & $\begin{array}{l}\text { Files and documents have been } \\
\text { required }\end{array}$ & $\begin{array}{l}\text { Credit Application files and } \\
\text { documents }\end{array}$ & $\begin{array}{l}\text { Files and documents have } \\
\text { been fulfilled }\end{array}$ \\
\hline \multicolumn{4}{|l|}{ Activity } \\
\hline $\begin{array}{l}\text { Implement Loan } \\
\text { Repayment }\end{array}$ & The statement credit repayment & $\begin{array}{l}\text { Credit monitoring } \\
\text { documents results }\end{array}$ & $\begin{array}{l}\text { Credit monitoring results } \\
\text { are completed }\end{array}$ \\
\hline $\begin{array}{l}\text { Implement Credit } \\
\text { Monitoring }\end{array}$ & Bookkeeping Credit statement & $\begin{array}{l}\text { Bookkeeping credit } \\
\text { documents }\end{array}$ & $\begin{array}{l}\text { Credit Approval process } \\
\text { completed }\end{array}$ \\
\hline $\begin{array}{l}\text { Perform Credit } \\
\text { Approval }\end{array}$ & Credit Analysis requirement & $\begin{array}{l}\text { Evidence of Credit } \\
\text { Analysis results }\end{array}$ & $\begin{array}{l}\text { Available credit analysis } \\
\text { results have been resolved }\end{array}$ \\
\hline $\begin{array}{l}\text { Perform Credit } \\
\text { Analysis }\end{array}$ & $\begin{array}{l}\text { Data and Document } \\
\text { Verification }\end{array}$ & $\begin{array}{l}\text { OTS, BI Checking, Trade } \\
\text { Checking }\end{array}$ & $\begin{array}{l}\text { Application files will be } \\
\text { analyzed }\end{array}$ \\
\hline $\begin{array}{l}\text { Accepting Credit } \\
\text { Application Documents }\end{array}$ & $\begin{array}{l}\text { Credit Application } \\
\text { Requirement }\end{array}$ & $\begin{array}{l}\text { Identity of Customer } \\
\text { Permit, Finance, Copy of } \\
\text { Collateral Document }\end{array}$ & $\begin{array}{l}\text { Credit Application files } \\
\text { collected }\end{array}$ \\
\hline
\end{tabular}




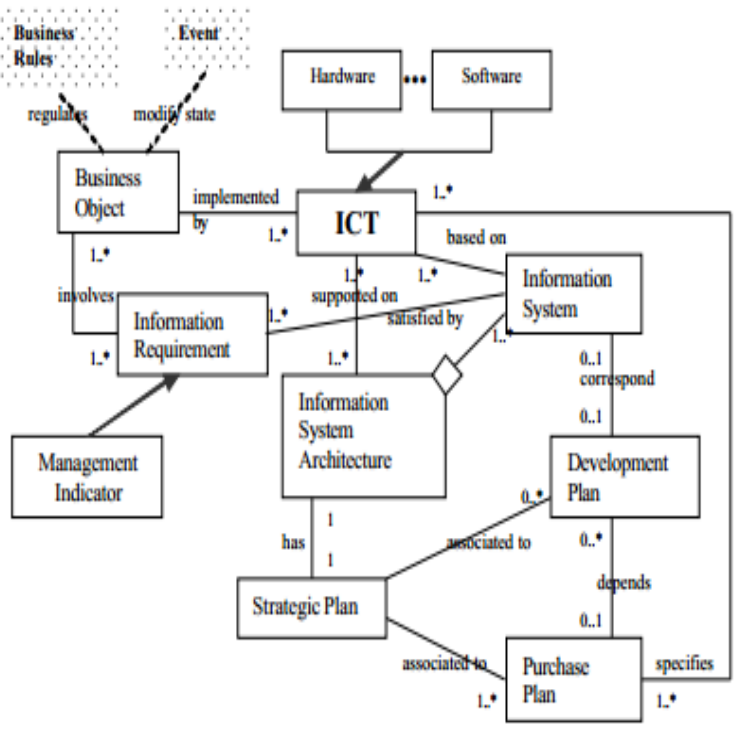

Fig. 8 Information System Model [7]

\section{Process Modeling :}

Data Flow Diagram is one information system modeling tool that illustrates the process that exists in the system. Modeling process by using Data Flow Diagram aims to show the flow of data in an information system. However, the process model is very important in defining the requirements in a graphical view [14].

Data Flow Diagram shown in the modeling of this information system is Context Diagram and Overview Diagram.

Context diagram is a Data Flow Diagram illustrating the scope of the Monitoring and Evaluation System for Banking Credit. Furthermore, Overview Diagram This diagram illustrates where the overall process that occurs in the monitoring and evaluation system for bank credit.

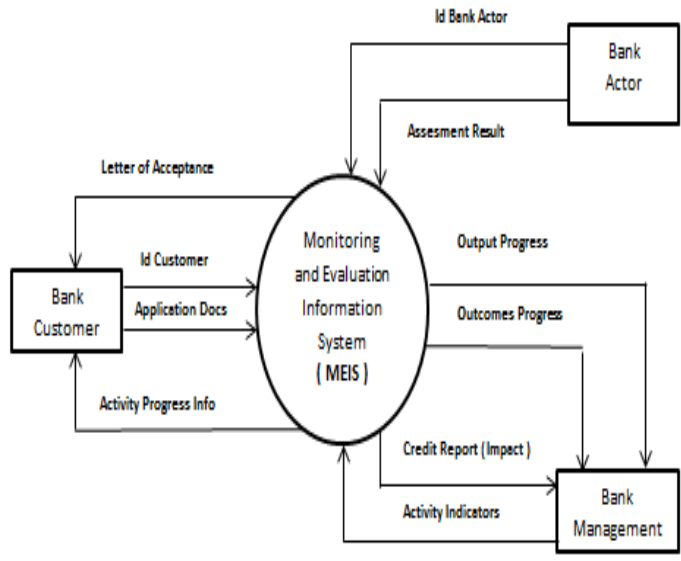

Fig. 9 Context Diagram of MEIS
Figure 12 shows the MEIS for banking credit Context Diagram (as a process) : ID Bank Customer Credit, Application Documents, Payment Vouchers and Cash are input of the M\&N System For Banking Credit while letter of Acceptance Documents, Output Progress, Outcomes Progress, and the Credit Report/Impact are the output of the same system. The functional data flow diagram is reflected in figure 9 .

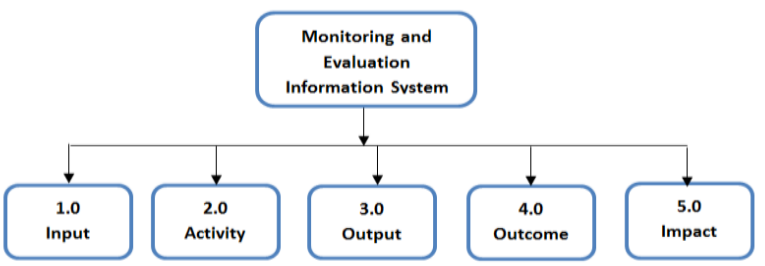

Fig. 10 First Level decomposition of MEIS

Figure 10 shows the first level functional decomposition chart of the M\&E process modeling. Each process in the decomposition is a parent process. In this case, each process in the first level decomposition is a parent process that has children processes. Figure 11 illustrates the next decomposition level.

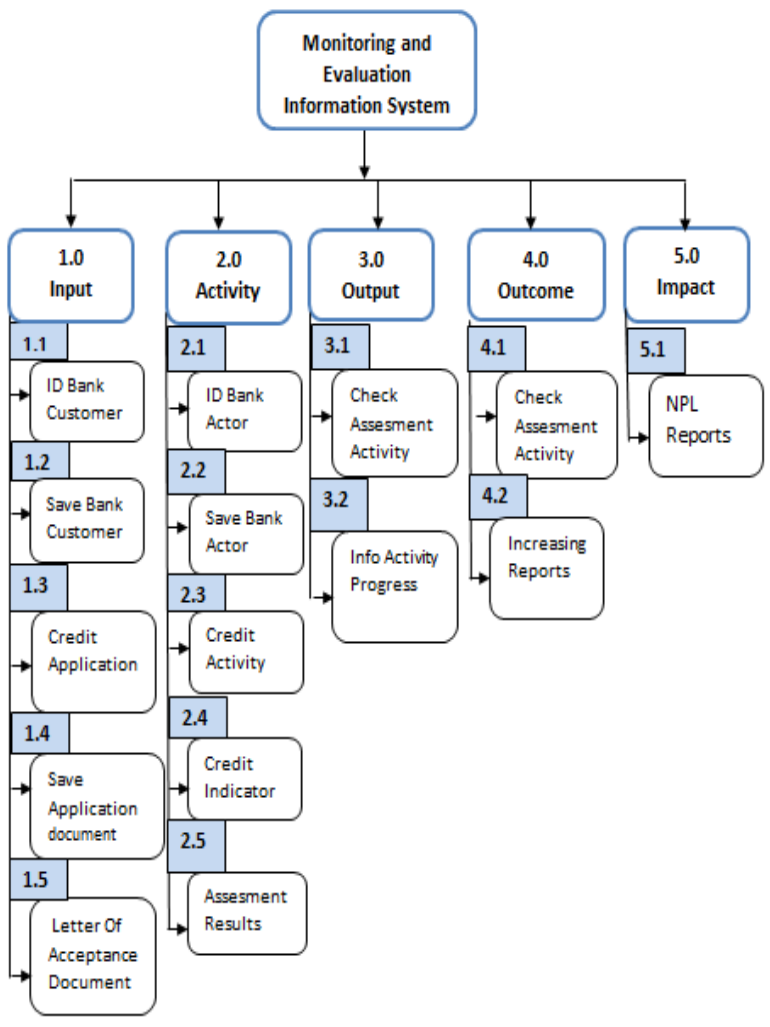

Fig. 11 Second Level Decomposition of MEIS 


\section{Data Modeling :}

In general, data requirements for systems development and maintenance must be modeled using Entity Relationship Diagrams.

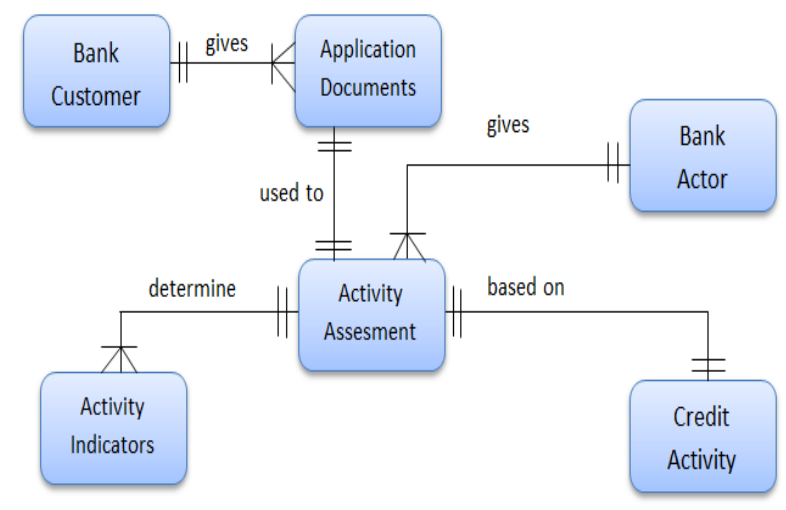

Fig. 12 Context Data Model for M\&E Process

According to Yakubu et al [13], stated that context data model is a data analysis model that includes all entities discovered as well as their relationship and no attributes. Context data model reflect new system requirement and scope. Data model preparation for implementation as database. The process of preparing a data model is called Normalization. Each entity in Figure 12 was normalized before representing it in Database Model. Figure 13. depicts Database Entity Relationship Diagram of the monitoring and evaluation process model in Figure12.

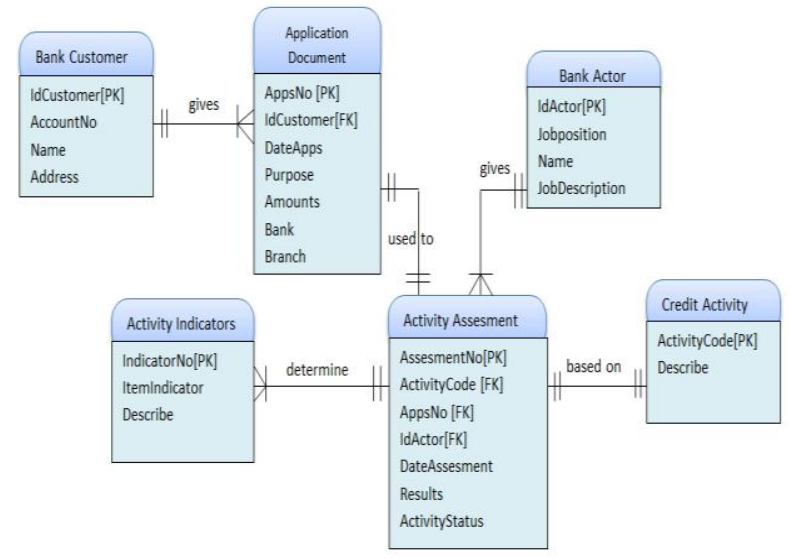

Fig. 13 Database Model for M\&E Process

\section{Information System Architecture :}

Information System Architecture is typically used to complement the results of an Information Modeling System. In Figure 14, it is the described the operations provided by the Credit Banking Business Services (and which IT components implemented it).

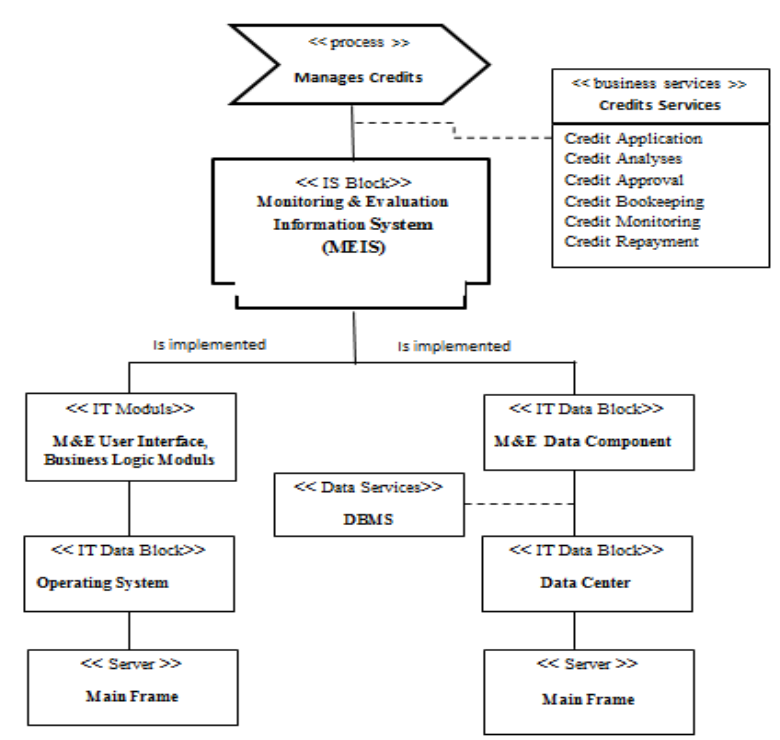

Fig. 14 Information System Architecture

As described the Information System Architecture in Figure 14, the MEIS «IS Block» is implemented through two «IT Blocks» (one for data and another for logic and user interface), supported in «IT Platforms» and a mainframe computer.

\subsection{Evaluation and Implication}

The model evaluation using a confirm-ability test, where the test is used to test the reliability and validity of the model. Researchers invited banking practitioners and experts who know the problem of information systems and understand the field of banking credit information system modeling. The qualitative experiment showed that 3 persons as Bank Practitioners and 2 persons of the experts Banking Information System in Jakarta, stated that $80 \%$ of practitioners and experts banking information system confirm on the proposed modeling information system of monitoring and evaluation for banking credit and 20\% confirmed but with some notes.

The theoretical implication of this study is necessary to have a strong understanding of related concepts of monitoring and evaluation should be translated into the process of banking credit Furthermore, modeled in an information system that supports the management of the Bank to minimize the amount of Non-Performing Loans, so that bank credit system more qualified. Technically, EKD-CMM approach in conducting information system modeling has implications for the contribution to the decision making process and accurately in a modern 
organization that is highly dependent on information and communication technology. Thus, this model will strengthen the bank's ability to apply them to adopt a knowledge-based system development. Managerial implications, Bank XYZ must be able to have good resources in understanding the EKD-CMM and supporting technologies that have a major impact in the success of the banking business objective.

\section{Conclusions}

This study has proposed the development of MEIS concept to solve the problem in banking credit. The main contribution of this research is the application of monitoring and evaluation concept and the use of EKDCMM to describe the information system modelling for banking credit.

The paper also presented a real-world case study, which is taken from a project in one of the Regional Development Bank in Indonesia, namely the Bank XYZ. The case study is utilized to illustrate the proposal with concrete information systems modelling that is analyzed from the perspective of banking management, information system and technological aspect.

Finally, this research can be further developed by implementing the computer-based system applications and integrating the proposed model with other systems owned by Bank XYZ. As future work, we intend to further evaluate the proposed model more accurately before it can be applied in a real-world system or working environment.

\section{References}

[1] IBI (Ikatan Bankir Indonesia). "Memahami Bisnis Bank. Modul Sertifikasi Tingkat I General Banking”,Jakarta:PT Gramedia Pustaka Utama, 2013.

[2] A. Mayasari, dan D. Budi Setiawan, "Rasio Permodalan Pada Bank Pembangunan Daerah", Journal of Business and Banking, Vol. 3, No. 1, May 2013, pp. 119-134.

[3] J.Z. Kusek, and C.R. Rist, "Ten Steps to a Results-Based Monitoring and Evaluation System, : A handbook for development practitioners". Washington D.C.: The World Bank, 2004.

[4] OECD (Organization for Economic Co-operation and Development). "Glossary of Key Terms in Evaluation and Results-Based Management." Paris: OECD/DAC.2002

[5] Z. Hardlife and G. Zhou, G. "Utilization of Monitoring and Evaluation Systems by Development Agencies: The Case of the UNDP in Zimbabwe". American International Journal of Contemporary Research. Vol. 3 No. 3; March 2013

[6] P. Crawford and P. Bryce, P." Project monitoring and evaluation: a method for enhancing the efficiency and effectiveness of aid project implementation", International Journal of Project Management 21. 2003.pp:363-373.
[7] S. Nurcan, and J. Barrios. "Enterprise Knowledge and Information System Modeling in an Evolving Environment., International Workshop on Engineering Methods Engineering Methods to Support Information Systems Evolution”, (EMSISE-2003), Geneva, Switzerland, September 2-5, 2003, pp: 61-74.

[8] U. Sekaran. Research Method for Business: A Skill Building Approach". $2^{\text {nd }}$ Edition. John Wiley and Sons, Inc. NewYork.2003.

[9] P.M Mugo and M.O Oleche," Monitoring and Evaluation of Development Projects and Economic Growth in Kenya", International Journal of Novel Research in Humanity and Social Sciences, Vol. 2, Issue 6, pp: (52-63), Month: November-December 2015, ISSN 2394-9694.

[10] S. Karouw. " Using Agile and Spatial Approach to Modeling Monitoring and Evaluation Information System: Case Study of Manado City, Indonesia", $3^{\text {rd }}$ World Conference on Applied Sciences, Engineering \& Technology, 27-29 September 2014, Kathmandu, Nepal.2014.

[11] J.A O'Brien. "Introduction to information systems: essentials for the e-business enterprise". McGrawHill, Boston, MA.2003.

[12] A. Vasconcelos, P. Sousa, and J. Tribolet. "Information System Architectures: Representation, Planning and Evaluation", Systemics, Cybernetics and Informatics, Volume 1 No. 6 pp: 78-84.

[13] F. Yakubu, B. Isma'eel Ahmad, O.M Omowumi and M.A Mngohol.," Process and Database Modeling of a University Bursary System: A Perspective of Cash Office", International Journal of Computer Science Issues, Vol. 8, Issue 4, No 2, July 2011, pp: 555-559.

[14] E. Ziemba and I. Obłąk. "Change management in information systems projects for public organizations in Poland". Interdisciplinary Journal of Information, Knowledge, and Management, 10,pp: 47-62

[15] R. Ibrahim and S. Yen Yen." Formulalization of The Data Flow Diagram Rules for Consistency Check". International Journal of Software Engineering \& Applications (IJSEA), Vol.1, No.4, October 2010, pp: 95-111.

\footnotetext{
Mercurius Broto Legowo is a Lecturer of Faculty of Information Technology in Information System Department at Perbanas Institute, Jakarta, Indonesia, involved in research and teaching activities. He received his Master in Computer Science at STMIK Eresha, Jakarta, Indonesia, 2012 and currently he is a Program Doctor of Research in Management Student at Bina Nusantara University, Jakarta, Indonesia. His interests are Business Information System and Business Intelligence Research.
} 